\title{
Mapping of Soil Properties under Different Land Uses in Lesser Karakoram Range, Pakistan
}

\author{
Azfar Hussain ${ }^{1,2}$, Haibat Ali ${ }^{3}$, Farida Begum ${ }^{3}$, Azhar Hussain ${ }^{4}$, \\ Muhammad Zafar Khan ${ }^{3}$, Yinghui Guan ${ }^{1,2}$, Jinxing Zhou ${ }^{1,2 *}$, \\ Saif-Ud-Din ${ }^{3}$, Kiramat Hussain ${ }^{5}$
}

${ }^{1}$ Jianshui Research Station, School of Soil and Water Conservation, Beijing Forestry University, Beijing 100083, China

${ }^{2}$ Key Laboratory of State Forestry and Grassland Administration on Soil and Water Conservation, Beijing Forestry University, Beijing 100083, China

${ }^{3}$ Department of Environmental Sciences, Karakoram International University, Gilgit 15100, Pakistan ${ }^{4}$ Department of Agriculture and Food Technology, Karakoram International University, Gilgit 15100, Pakistan

${ }^{5}$ Forest, Wildlife and Environment Department of Gilgit Baltistan, Pakistan

Received: 28 January 2020

Accepted: 14 May 2020

\begin{abstract}
The vulnerability to environmental changes requires appropriate management of mountainous soils to harmonize agriculture productivity and health of agro-ecosystem. Information on spatial analyses in land uses is important for site-specific nutrient management. The current study investigates and maps soil properties in two land use types (agriculture and orchard) through geostatistical analyses of selected parameters using Inverse Distance Weighting (IDW). Geo-referenced soil samples were collected at 0-15 cm depth. Overall, silty loam soils were observed with slightly alkaline $\mathrm{pH}$, normal electrical conductivity and adequate organic carbon in both land use types. Macronutrient results indicated that nitrate-nitrogen was medium while phosphorus and potassium were higher in both land uses. The two-way ANOVA indicated that the EC $(p<0.05), \mathrm{NO}_{3}-\mathrm{N}, \mathrm{Av} . \mathrm{P}$ and Ex. K $(p<0.001)$ differed significantly across the land use types. Whereas with respect to various study locations the EC and Av. $\mathrm{P}$ differed significantly $(p<0.01)$, while $\mathrm{pH}, \mathrm{SOC}, \mathrm{NO}_{3}-\mathrm{N}, \mathrm{Ex} . \mathrm{K}$ and saturation did vary. Higher Soil quality index (SQI) in agriculture soil indicating better quality or health than the orchard. The findings provide useful insights for soil fertility management in mountainous agro-ecosystems.
\end{abstract}

Keywords: fertility management, Karakoram, land use, spatial analyses, Soil Quality Index

*e-mail: zjx001@bjfu.edu.cn 


\section{Introduction}

The interactions of soil chemical, physical and biological properties define a particular soil's quality and determine how effectively the soil performs ecosystem functions [1]. The anthropogenic conversion of forest and rangelands into agricultural lands greatly alter ecological functions of soils. Fertility and quality of soil also depend upon the cropping system and farming practices, which affect the fertility quality and yield production [2]. Constant tillage in soil and the use of diverse agro-chemicals has severe effects on soil biodiversity and its habitats [3]. For assessment of soil quality, scientists have proposed some parameters such as Soil organic carbon (SOC), soil $\mathrm{pH}$, nitrate-nitrogen $\left(\mathrm{NO}_{3}-\mathrm{N}\right)$, available $\mathrm{P}$ (Av. P), exchangeable K (Ex. K) and electrical conductivity (EC) [4-6]. Soil organic matter (SOM) has positive effects on soil chemical and physical properties as it plays a role in the supply of SOC and is the main energy source for the soil microorganism to perform their biological soil practice [7].

Geospatial tools and techniques are increasingly in use by soil scientists to map soil properties across wide ranges of geographic and topographic region. Such mapping is important for land use planning, fertility management, better yields and sustainable agroecosystem management. The maps generated through the geostatistical analysis also help in the monitoring of the nutrient status of soil [8]. Spatial analysis of soil properties provides information about nutrient availability and its management, which will help in the application of fertilizer use in the area. It is also beneficial for farmers to get more crop yields [9].

Land cover is one of the most important data used to demonstrate the effects of land use changes, especially human activities. Production of land use maps can be done by using different methods on satellite images. Some studies have produced land cover maps of the controlled classification technique over Landsat satellite imagery. By using land cover maps, the changes in urban development and green areas over time have been evaluated. At the same time, the relationship between changes in the land cover over time and changes in the urban population has been examined. Agriculture planning has many benefits in terms of the environment. Agricultural landscape planning means making decisions about the future situation of agriculture land. In this case, it is necessary to predict how the land has changed over time and the effects of natural factors and human activities on the land. In this way, successful and sustainable landscape planning studies can be accomplished [10-14]. Different land use type has a deep effect on SOC storage because it affects the amount and quality of litter input, decomposition rate, and stabilization of SOC [15]. Nitrous oxide $\left(\mathrm{N}_{2} \mathrm{O}\right)$ is a major greenhouse gas produces from these factors [16] which also affects ozone [17].

Land use change practices have a great effect on the distribution and supply of soil nutrients. SOM gains or losses in a short time is difficult to measure because of a large amount of organic matter in soils and spatial analysis of soil, especially in forest soils. Such kind of changes in soil properties lead to soil erosion [18]. Land use changes have major effect on the diversity and the amount of biomass returned to the soil, which also disorders the richness of nutrients restored to the soil. The change in forest cover to other forms of land such as grasslands and plantation results in great variation of canopy cover, this affects the supply of SOC, due to change in soil temperature and moisture regimes [19].

Population growth and economic factors are the two main forces behind the demand for food production, crop production and fertilizers use in Nepal [20]. [21] Reported that $\mathrm{OM}$ in forest and pastures is higher than arable land in Bagrot valley, Gilgit, Pakistan. Due to the higher use of animal dung and green manure, chemical properties like SOC and $\mathrm{NO}_{3}-\mathrm{N}$ was found higher in Shiskat valley [22]. According to [22] the SOC and fertility status in Altit valley was ideal due to the use of organic fertilizers. There was a great variation in the SOC content in different forest catchments of Bagrot forest [23].

Mountainous landscapes have serious problems of soil degradation and in the last few years, the problem has been escalating due to the increase in population growth leading to land scarcity in the fragile mountains. With increase in population, human settlements on slopes, overgrazing and deforestation natural habitats have depleted. Mountainous soils are vulnerable to environmental changes; therefore, their fertility management is essential to enhance agricultural productivity and sustain agro-ecosystems $[23,24]$. The present study seeks to investigate and map soil properties under different land use types across different geographic locations at a selected site in Karakoram Mountain of northern Pakistan.

\section{Objects and Method}

\section{Study Area}

Gilgit-Baltistan (GB) encompasses between $35^{\circ}-37^{\circ} \mathrm{N}$ and $72^{\circ}-75^{\circ} \mathrm{E}$ of Pakistan bordering with China through Xinxiang province. It has mountainous landscape elevation ranging between $1500 \mathrm{~m}-4,500 \mathrm{~m}$ sea level and the place where world three famous mountain ranges Hindukush, Himalaya and Karakoram meet. It covers an area of $72496 \mathrm{~km}^{2}$, with approximately 1.5 million people, with the density of 10 persons $/ \mathrm{km}^{2}$. About $0.96 \%$ of land is cultivable whereas, approx. 60,000 hectares is barren, which could be cultivable land if irrigation available and the rest is comprised of mountains, rangeland, lakes/rivers and forests etc [25]. The study area comprised of two villages of Karakoram mountains in northern Pakistan, namely Jalalabad and Oshikhandas, located at the elevation of $1503 \mathrm{~m}$ and $1475 \mathrm{~m}$ having latitude and longitude of $35.8815^{\circ}$, 
$74.498^{\circ}$, and $35.8846^{\circ}, 74.4649^{\circ}$, respectively (Fig. 1). The major land use types in the investigated area are cultivated cropland, orchards, forest planation at the hill slope and barren land where irrigation is not possible. The natural vegetation of Jalalabad and Oshikhandas consists of trees, grasses and bushes. The major dominated tree species in the study area are willow (Salix spp), poplars (Poplus spp), mulberry (Morus spp), apricot (Prunus spp), and Russian olive (Elaeagnus spp). The farming system in both the villages are mixed type, which comprises of crop production and livestock rearing. Crop residues and leaf litter used for livestock bedding that undergoes composting along with animal dung, which is later applied to agriculture land as cattle manure. Both villages have snow and glacial fed irrigation system and network of channels to the agriculture land. The areas fall in double cropping zone and grow wheat and maize as major crop, further, they produce vegetables such as potato, mustard, pulses, beans, onion, cabbage and tomato in summer. Cattle manure along with chemical fertilizers are applied in agriculture land once in the month of December and January. The community use both tractor and traditional ox plowing to prepare the lands for cultivation.

\section{Sampling and Analysis}

Eighty soil samples were randomly collected from two land use types $(40 * 2=80$ agriculture and orchards). Samples were collected from a depth of 0 to $15 \mathrm{~cm}$ with the help of small spade and hand trowel. The samples were air-dried and passed through a $2 \mathrm{~mm}$ sieve for further laboratory analysis. $\mathrm{pH}$ was measured through a $\mathrm{pH}$ probe by 1:1 (soil: water) suspension with OAKTON PC 700 meter [26]. EC was measured by 1:5 (Soil: water) with Milwaukec EC meter (SM 302) [27]. SOC was measured by dry combustion method $[28,29]$. Saturation \% was determined as described by [30]. Fertility status of soil $\mathrm{NO}_{3}-\mathrm{N}, \mathrm{P}, \mathrm{K}$ was determined by Ammonium bicarbonate diethylene triamine penta acetic acid (AB- DTPA) extractable method [31]. Interpolation with Inverse distance weighting (IDW) in ArcGIS 10.3 was selected for mapping in this study [8]. IDW is used when sampling points are separated by large distances. Soil Quality Index (SQI)

The method was adapted from [32] and [33]. All the SQI values of each parameter of their ranges are summed to get a total SQI [32].

$$
\begin{gathered}
\text { Total SQI }=\sum \text { individual soil } \\
\text { properties index values. }
\end{gathered}
$$

The total SQI is then expressed as a percentage of the maximum possible value of the total SQI for the soil properties that are measured by using following equation.

$S Q I \%=\frac{\text { Total SQI }}{\text { maximum possible total SQI for properties measured }} \times 100$

\section{Statistical Analysis}

Two-way factorial ANOVA was applied to find any significant variation in soil quality between locations and among land uses. Pearson's correlation test was applied to determine the relation between investigated soil properties. Statistical analysis was performed using SPSS 20.

\section{Results and Discussion}

Influence of Location and Land Use Change on Soil Physio-Chemical Properties

EC $(p<0.05), \mathrm{NO}_{3}-\mathrm{N}$, Av. $\mathrm{P}$ and Ex. K $(p<0.001)$ differed significantly across the land use types. With respect to locations EC and Av. P differed significantly $(p<0.01), \quad(p<0.001)$ whereas $\mathrm{pH}, \mathrm{SOC}, \mathrm{NO}_{3}-\mathrm{N}$, Ex.
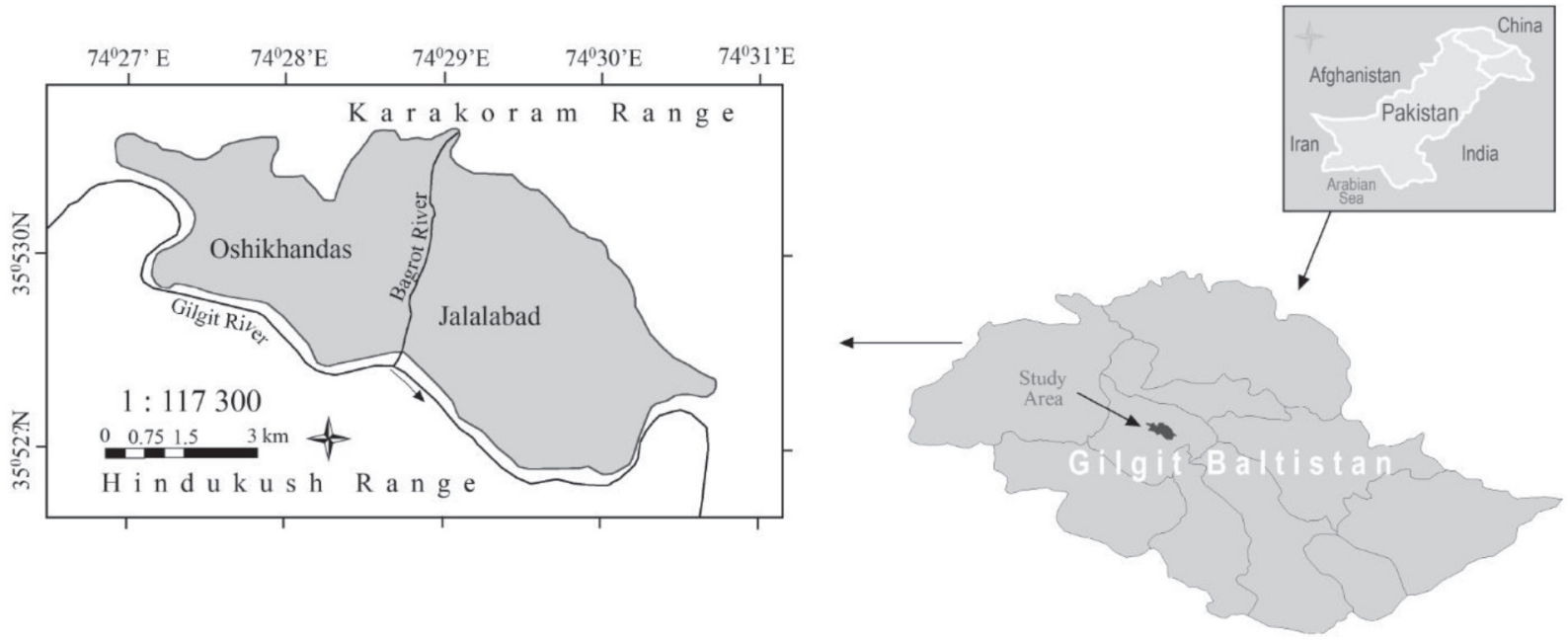

Fig. 1. Location map of Jalalabad and Oshikhandas. 
Table 1. Two-way Factorial ANOVA of relevant parameters by land use and location.

\begin{tabular}{|c|c|c|c|c|c|c|c|}
\hline & $\mathrm{pH}$ & $\mathrm{EC}$ & $\mathrm{SOC}$ & $\mathrm{NO}_{3}-\mathrm{N}$ & Av. P & Ex. K & Saturation \\
\hline Location & $.633^{\mathrm{ns}}$ & $.009^{* *}$ & $.667^{\mathrm{ns}}$ & $.200^{\mathrm{ns}}$ & $.000^{* * *}$ & $.461^{\mathrm{ns}}$ & $.435^{\mathrm{ns}}$ \\
\hline Land Use & $.210^{\mathrm{ns}}$ & $.026^{*}$ & $.270^{\mathrm{ns}}$ & $.000^{* * *}$ & $.000^{* * *}$ & $.000^{* * *}$ & $.846^{\mathrm{ns}}$ \\
\hline
\end{tabular}

Note: *, **, ***, \& "ns" indicate $\mathrm{p}<0.05(5 \%), \mathrm{p}<0.01(1 \%), \mathrm{p}<0.001$ and "ns" non-significant respectively

Table 2. Comparative soil properties among agriculture and orchard (land uses).

\begin{tabular}{|c|c|c|c|c|c|c|c|c|c|}
\hline Land Use & Variable & Unit & Mean & S.D. & Min & Max & Variance & Skew & Kurt \\
\hline \multirow{7}{*}{ Agriculture } & $\mathrm{pH}$ & & 7.75 & .12 & 7.50 & 7.90 & .015 & -.687 & -.016 \\
\hline & EC & $\mathrm{mS} / \mathrm{cm}$ & 1.17 & .24 & 1 & 1.50 & .060 & .681 & -1.71 \\
\hline & SOC & $\%$ & 2.64 & 1.30 & .83 & 4.97 & 1.71 & .549 & -1.024 \\
\hline & $\mathrm{NO}_{3}-\mathrm{N}$ & ppm & 19.47 & 2.61 & 12.97 & 24.67 & 6.84 & -.561 & 1.009 \\
\hline & Av. P & ppm & 16.62 & 3.38 & 10.46 & 21.73 & 11.46 & -.130 & -.030 \\
\hline & Ex. K & ppm & 360.90 & 61.36 & 252 & 468 & 376 & -.119 & -.538 \\
\hline & Sat & $\%$ & 40.05 & 3.60 & 35 & 48 & 12.99 & .621 & -.199 \\
\hline \multirow{7}{*}{ Orchard } & $\mathrm{pH}$ & & 7.69 & .19 & 7.30 & 7.90 & .037 & -.690 & -.860 \\
\hline & $\mathrm{EC}$ & $\mathrm{mS} / \mathrm{cm}$ & 1.47 & .52 & 1 & 2.50 & .276 & 1.01 & .068 \\
\hline & SOC & $\%$ & 3.04 & .93 & 1.29 & 4.42 & .875 & -.223 & -.784 \\
\hline & $\mathrm{NO}_{3}-\mathrm{N}$ & ppm & 13.16 & 2.46 & 9.17 & 13.40 & 6.09 & .082 & -.896 \\
\hline & Av. P & ppm & 10.07 & 4.49 & 4.43 & 17.71 & 20.16 & .475 & -1.176 \\
\hline & Ex. K & ppm & 252.40 & 50.40 & 192 & 374 & 254 & .993 & .796 \\
\hline & Sat & $\%$ & 40.25 & 2.80 & 35 & 45 & 7.88 & -.491 & -.269 \\
\hline
\end{tabular}

Min: minimum value; Max: maximum value; S.D.: standard deviation; Skew: skewness; Kurt; Kurtosis

Table 3. Comparative soil properties among Jalalabad and Oshikhandas (locations).

\begin{tabular}{|c|c|c|c|c|c|c|c|c|c|}
\hline Location & Variable & Unit & Mean & S.D. & Min & Max & Variance & Skew & Kurt \\
\hline \multirow{7}{*}{ Jalalabad } & $\mathrm{pH}$ & & 7.71 & .17 & 7.30 & 7.90 & .029 & -1 & .409 \\
\hline & $\mathrm{EC}$ & $\mathrm{mS} / \mathrm{cm}$ & 1.50 & .51 & 1 & 2.50 & .263 & .975 & .112 \\
\hline & SOC & $\%$ & 2.92 & 1.33 & .83 & 4.97 & 1.79 & .061 & -1.4 \\
\hline & $\mathrm{NO}_{3}-\mathrm{N}$ & $\mathrm{ppm}$ & 17.14 & 4.66 & 9.17 & 24.67 & 21.79 & -.377 & -.973 \\
\hline & Av. P & ppm & 10.29 & 4.54 & 4.43 & 19.92 & 20.65 & .409 & -.846 \\
\hline & Ex. K & $\mathrm{ppm}$ & 297 & 79.19 & 192 & 468 & 627 & .395 & -.632 \\
\hline & Sat & $\%$ & 40.55 & 2.79 & 35 & 45 & 7.83 & -.219 & -.474 \\
\hline \multirow{7}{*}{ Oshikhandas } & $\mathrm{pH}$ & & 7.73 & .15 & 7.40 & 7.90 & .024 & -.835 & -.421 \\
\hline & $\mathrm{EC}$ & $\mathrm{mS} / \mathrm{cm}$ & 1.15 & .23 & 1 & 1.50 & .055 & 945 & -1.24 \\
\hline & SOC & $\%$ & 2.76 & .93 & 1.29 & 4.42 & .869 & .120 & -.809 \\
\hline & $\mathrm{NO}_{3}-\mathrm{N}$ & ppm & 15.48 & 3.26 & 10.12 & 20.56 & 10.64 & .190 & -1.22 \\
\hline & Av. P & ppm & 16.40 & 3.73 & 9.66 & 21.73 & 13.92 & -.518 & -.602 \\
\hline & Ex. K & ppm & 315.90 & 77.78 & 196 & 452 & 604 & .280 & -1.16 \\
\hline & Sat & $\%$ & 39.75 & 3.56 & 35 & 48 & 12.72 & .614 & .158 \\
\hline
\end{tabular}

Min: minimum value; Max: maximum value; S.D.: standard deviation; Skew: skewness; Kurt; Kurtosis 
$\mathrm{K}$ and saturation did not vary across the locations (Table 1).

Soil pH was slightly higher in agriculture (Table 2) while with respect to the location it was found to be slightly higher in Oshikhandas (Table 3). Mapping of $\mathrm{pH}$ by GIS technique showed that above $83.16 \%$ area contained $\mathrm{pH}$ concentration of agriculture in the range of 7.63-7.81; while in orchards $62.9 \%$ area fall in ranges of 7.63-7.81 (Fig. 2). Soil $\mathrm{pH}$ is the sign of acidity and alkalinity in the soil, the availability of nutrients to plants depends upon it $[6,34]$. The majority of the soil nutrients are present in slightly acidic soils as compared to neutral and alkaline soils. The mean soil pH of two land use types in Jalalabad and Oshikhandas showed a slight variation. $\mathrm{pH}$ was slightly alkaline in nature; this may be due to an accumulation of soluble salts, classified as alkaline soil [35]. Soils in agricultural and orchards slightly varied $\mathrm{pH}$, possibly due to the presence of different nutrient cycling and slightly different vegetation cover [36]. Soil EC is higher in orchards as compared to agriculture (Table 2); it is higher in Jalalabad as compared to Oshikhandas (Table 3). Mapping of EC by GIS technique showed that about $76.21 \%$ of the agriculture area contains EC in the range of $1.15-1.35 \mathrm{mS} / \mathrm{cm}$; while in orchards, $77.42 \%$ area contains the range of $1.15-1.60 \mathrm{mS} / \mathrm{cm}$ (Fig. 2).
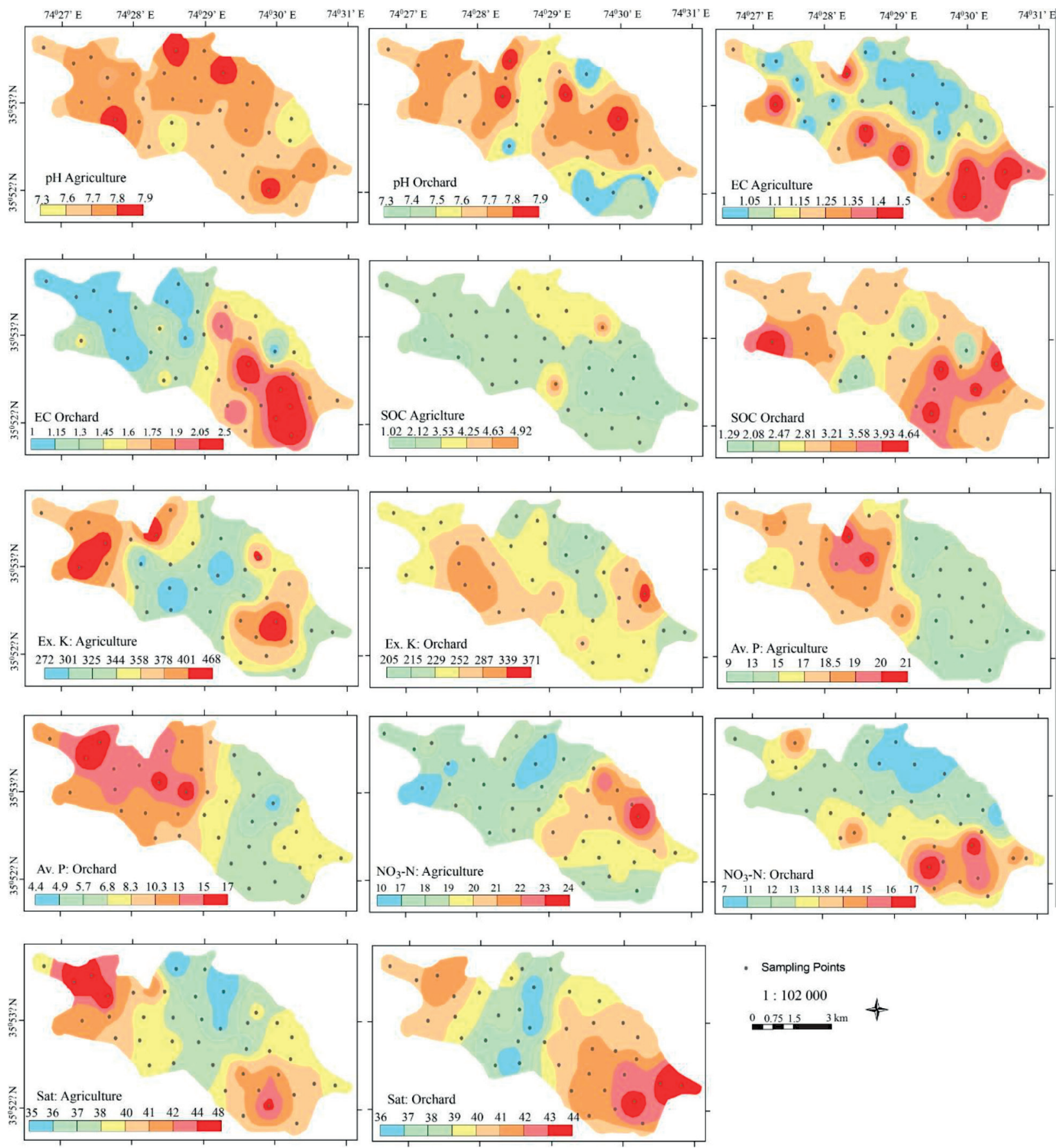

Fig. 2. IDW maps of $\mathrm{pH}, \mathrm{EC}, \mathrm{SOC}, \mathrm{NO}_{3}-\mathrm{N}, \mathrm{Av}$. P, Ex. $\mathrm{K}$ and saturation in both land uses and locations. 
Pearson's correlation indicated that EC was significantly correlated with Av. P $(p<0.01)$, Ex. K $(p<0.05)$ and soil saturation $(p<0.05)$ (Table 4$)$.

$\mathrm{EC}$ is an important indicator of soil health and is a measure of different salts in soil that affects the crop yields [37]. Mean Soil EC in Jalalabad orchards was higher as compared to agriculture, this could be attributed to high NO3-N, SOC and base saturation in the soil [35]. One major reason for increasing salts in cultivated lands is due to the use of chemical fertilizers [38]. The mean readings of both soils are $1.4 \mathrm{mS} / \mathrm{cm}$, which indicates the soil is good in the form of nutrient availability and microbial activity, which helps plant growth. SOC is higher in the orchard as compared to agriculture (Table 2) while it is higher in Jalalabad as compared to Oshikhandas (Table 3). Spatial analysis of SOC showed that above $73.9 \%$ area contains SOC concentration of agriculture in the range of $2.12-4.62 \%$ while in orchards $65.41 \%$ area contains SOC concentration in the range of $3.57-5 \%$ (Fig. 2). SOC is the main resource of energy to the microorganisms present in soil and also affects nutrient availability and the soil health also depends upon it [39], and used to mitigate consequences of climate change [40]. A higher amount of SOC content in orchards may be due to the maximum amount of litter fall and its decomposition as it was noticed during soil sampling. The amount of soil organic carbon content depends upon the organic matter presents in soil [41]. SOC in agriculture was normal in range; it can be affected by use of fertilizers and animal manure that can increase the SOC levels $[42,43]$. Another reason may be due to the agricultural management and rotation of the crops in the fields including maize, wheat and potato, which affects the accumulation rate of SOC. The farming management system and soil type also have a great influence on SOC content [44].

$\mathrm{NO}_{3}-\mathrm{N}$ was higher in agriculture as compared to the orchard (Table 2) while it was higher in Jalalabad as compared to Oshikhandas (Table 3). Spatial analysis of $\mathrm{NO}_{3}-\mathrm{N}$ showed that above $65.89 \%$ area contains $\mathrm{NO}_{3}-\mathrm{N}$ concentration of agriculture in the range of $16.95-20.55 \mathrm{ppm}$; while in orchards, $60.47 \%$ area contains $\mathrm{NO}_{3}-\mathrm{N}$ concentration in the range of 10.98-13.89 ppm (Fig. 2). Nitrogen was applied in the form of ammonium nitrate in agriculture and is an important indicator that is used for the evaluation of soil fertility [45]. Decay and accumulation of leaf litter in orchards due to trees could have possibly resulted in high fertility in the orchards [46], while in agriculture it may be due to the application of commercial fertilizers and animal manure. As both agriculture and orchards fall in the medium category of soil fertility levels. The amount of $\mathrm{NO}_{3}-\mathrm{N}$ in agriculture was slightly higher than orchards. Forest and grasslands store the maximum amount of SOC and nitrogen [47]. From geographical perspective [22] found higher results of $\mathrm{NO}_{3}-\mathrm{N}$ in agriculture soil of Altit valley Hunza, while [35] held that Gilgit soils are deficient of nitrogen having $0.08 \%$ only.

Av. P was significantly higher in agriculture as compared to orchards (Table 2) while it was significantly higher in Oshikhandas as compared to Jalalabad (Table 3). Spatial analysis of Av. P showed that about $60.03 \%$ area contains its concentration of agriculture in the range of $13.75-18.56 \mathrm{ppm}$; while in orchards, $52.06 \%$ area contains phosphorus concentration in the range of 5.75-10.33 ppm (Fig. 2). Pearson's correlation indicated that Av. P was highly correlated with EC $(p<0.01)$, $\mathrm{NO}_{3}$-N $(p<0.01)$ Ex. K $(p<0.01)$ (Table 4). Due to the use of fertilizers, the phosphorus accumulates in the surface of the soil in cultivated lands. One major reason for the higher values of Av. P in agriculture is due to the use of commercial fertilizers [22]. Agricultural phosphorus properly falls in the high category having a mean $16 \mathrm{ppm}$; which means that the soils of both villages have the required amount of Av. P, which is suitable for crop growth. Good enough amount of Av. P in agriculture may be due to the application of synthetic fertilizers and animal manure while in orchards it may be due to decay of leaf litter and organic matter [22], who reported similar results of Av. P in Altit valley of the Karakoram Range in Gilgit.

Ex. $\mathrm{K}$ was also significantly higher in agriculture as compared to orchards (Table 2) while it was higher in Oshikhandas as compared to Jalalabad (Table 3).

Table 4. Pearson's correlation among measured soil properties.

\begin{tabular}{|c|c|c|c|c|c|c|c|}
\hline & $\mathrm{pH}$ & $\mathrm{EC}$ & SOC & $\mathrm{NO}_{3}-\mathrm{N}$ & Av. P & Ex. K & Sat \\
\hline $\mathrm{pH}$ & 1 & & & & & & \\
\hline $\mathrm{EC}$ & -.180 & 1 & & & & & \\
\hline SOC & .074 & .038 & 1 & & & & \\
\hline $\mathrm{N}$ & .029 & -.139 & -.158 & 1 & & & \\
\hline Av. P & .144 & $-.492^{* *}$ & -.167 & $.426^{* *}$ & 1 & & \\
\hline Ex. K & .189 & $-.315^{*}$ & -.219 & $.522^{* *}$ & $.495^{* *}$ & 1 & \\
\hline Sat & .092 & $.354^{*}$ & -.241 & .086 & -.062 & .151 & 1 \\
\hline
\end{tabular}

* Correlation is significant at the 0.05 level, ** Correlation is significant at the 0.01 level (2-tailed) 
Spatial analysis of Ex. K showed that about 53.89\% area contains its concentration of agriculture in the range of $325.27-378.36 \mathrm{ppm}$; while in orchards $83.52 \%$ area has a concentration in the range of 215.04-287.07 ppm (Fig. 2). Pearson's correlation indicated that Ex. K was significantly correlated with EC $(p<0.05), \mathrm{NO}_{3}-\mathrm{N}(p<0.01)$ and Av. $\mathrm{P}(p<0.01)$. $\mathrm{NO}_{3}-\mathrm{N}$ was highly correlated with Av. $\mathrm{P} \quad(p<0.01)$, Ex. K $(p<0.01)$ (Table 4). Soil Ex. K was higher in agriculture than orchards. [7, 25] also noted similar findings of higher $\mathrm{NO}_{3}-\mathrm{N}$, Av. $\mathrm{P}$ and Ex. $\mathrm{K}$ in agriculture soil than the other land uses reported in Karakoram soils of Gilgit-Baltistan. [34] Also reported similar concentrations of potassium in forest and farmlands in Ethiopia. Good enough amount of Ex. $\mathrm{K}$ in agriculture may be due to the use of fertilizers while in orchards it may be due to the relative pumping of potassium from the subsoil by the vegetation in the orchards [34]. The current concentration of potassium in both land uses is good enough for soil fertility. [48] Observed a decrease in potassium concentration as the growing season progresses from summer to autumn. Soil texture controls the presence of nutrients in the soil, its water holding capacity also depends upon it [8]. Saturation percent has around the same percentage in both agriculture and orchard (Table 2) while on location it has the same results as land uses (Table 3).

The percentage of stones in the soil profile of agriculture and orchards is $1-2 \%$ and $5-6 \%$ respectively. The depth of soil respect to bedrock varied in both sites, being a mountainous region and the soil depth solely depends on the land formation and deposition of soil is different in different sampling locations so the average soil depth is $3-6 \mathrm{~m}$. Spatial analysis of Sat. percentage showed that above $71.60 \%$ area contains soil saturation of agriculture in the range of $37.64-42.67 \%$;

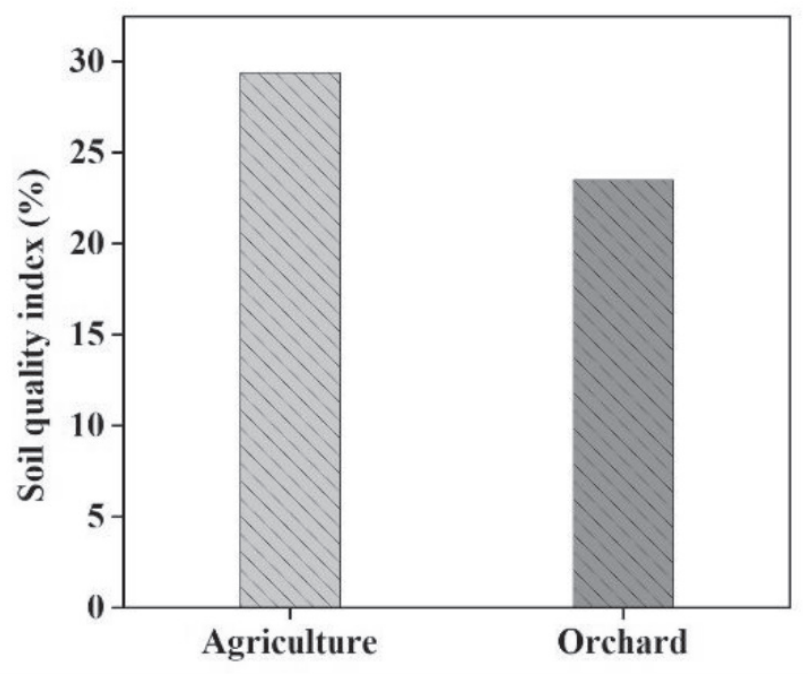

Fig. 3. Variation of soil quality index (SQI) in agriculture and orchards. while in orchards $68.28 \%$ area contains soil saturation in the range of $39-43 \%$ (Fig. 2). Pearson's correlation indicated that saturation was positively correlated with EC $(p<0.05)$ as expected (Table 4$)$. In the present study, the range of the soil saturation varied from $35 \%-48 \%$. The textural class of Gilgit soil varied from silt loam to silt clay [35]. Similar results were found by [22, 23] in different sites of Gilgit Baltistan.

\section{Soil Quality Index (SQI)}

SQI is used to examine the status of soil quality in both land uses. The average SQI values of agriculture and orchards are $29.41 \%$ and $23.49 \%$ respectively (Fig. 3). It is evident that there is an increase of 5-6\% in the soil quality in agriculture soil as compares to orchards, possibly attributed to the application of cattle manure along with chemical fertilizers. [33] Suggested that soil $\mathrm{pH}$ and organic matter has a great influence on the SQI yield. Soil EC and texture also had a great influence on the soil quality, as the texture of the area is silty loam; both the parameters are not considered in this SQI.

\section{Conclusions}

From the results, it is concluded that soil in both land uses is slightly alkaline in nature, silty loam with adequate SOC and good enough concentration of macronutrients. Higher soil quality index in agriculture soil showed better soil health compared to that in orchards. Spatial distribution maps developed through the IDW tool in GIS will be helpful for the policy makers and land manager in designing policy or taking fertility management decision for sustainable management of agro-ecosystem. Further research is required to understand the sustainable crop intensification on soil properties considering soil biodiversity and carbon stock under different cover crop for the sustainable management of agro-ecosystem and food security in the mountainous landscape.

\section{Acknowledgments}

NORHED-SUNREM Himalaya Project, the National Natural Science Foundation of China (Grant No. 41601279), the Special Fund for Forest Scientific Research in the Public Welfare (No. 201504401) and the Fundamental Research Funds for the Central Universities (2016ZCQ06 and 2015ZCQ-SB-01) funded this research.

\section{Conflict of Interest}

The authors declare no conflict of interest. 


\section{References}

1. REZAEI N., ROOZITALAB M., RAMEZANPOUR $H$. Effect of land use change on soil properties and clay mineralogy of forest soils developed in the Caspian Sea region of Iran, 14 (7) 1617, 2012.

2. JIN J.-W., XU Y.-F., YE H.-C., SHEN C.-Y., HUANG Y.F. Effect of land use and soil management practices on soil fertility quality in North China cities' urban fringe. African Journal of Agricultural Research, 6 (9), 2059, 2011.

3. BEGUM F., BAJRACHARYA R.M., SITAULA B.K., SHARMA S. Seasonal dynamics, slope aspect and land use effects on soil mesofauna density in the midhills of Nepal. International Journal of Biodiversity Science, Ecosystem Services \& Management, 9 (4), 290, 2013.

4. LARSON W., PIERCE F. Conservation and enhancement of soil quality. Paper presented at the Evaluation for sustainable land management in the developing world: proceedings of the International Workshop on Evaluation for Sustainable Land Management in the Developing World, Chiang Rai, Thailand, 15-21 September 1991.

5. DORAN, J. W. Soil health and sustainability. Advances in Agron., 56, 1, 1996.

6. BEGUM F., BAJRACHARYA R., SHARMA S. Land Use Effects On Soil Quality Indicators In The Mid-Hills Of Central Nepal. Paper presented at the International Conference on Emerging Technologies in Environmental Science and Engineering. Aligarh Muslim University, Aligarh, India 2009.

7. BEGUM F., ABBAS H., ALI S., ALI D., MUMTAZ S., KHAN M. Z., MIR N. Soil quality and organic carbon stock across the different land use in a mountainous landscape of Karakoram region, Gilgit, Pakistan. FEBFresenius Environmental Bulletin, 29 (01), 503, 2020.

8. KASHTANOV A., VERNYUK Y.I., SAVIN I.Y., SHCHEPOT'EV V., DOKUKIN P., SHARYCHEV D., LI K. Mapping of Rill Erosion of Arable Soils Based on Unmanned Aerial Vehicles Survey. Eurasian Soil Science, 51 (4), 479, 2018

9. THAKOR K.M., DHARAIYA N., SINGH V., PATE A., MEHMOOD K., KALUBARME M.H. Spatial variability mapping of micronutrients to improve productivity using Geo-informatics Tech-nology in Gujarat state, India. Int. J. Sci. Eng. Res, 5, 1021, 2014.

10. CETIN M. Consideration of permeable pavement in landscape architecture. Journal of Environmental Protection and Ecology, 16 (1), 385, 2015.

11. CETIN M. Change in amount of chlorophyll in some interior ornamental plants. Kastamonu University Journal of Engineering and Sciences, 3 (1), 11, 2017.

12. CETIN M. Using recycling materials for sustainable landscape planning, environment and ecology at the beginning of $21^{\text {st }}$ century, ST: Kliment Ohridski University Press, Sofia, Chapter 55, 2015.

13. CETIN M., SEVIK H., CANTURK U., CAKIR C. Evaluation of the recreational potential of Kutahya Urban Forest. Fresenius Environmental Bulletin, 27 (5), 2629, 2018.

14. CETIN M., ZEREN I., SEVIK H., CAKIR C., AKPINAR H. A study on the determination of the natural park's sustainable tourism potential. Environmental monitoring and assessment, 190 (3), 167, 2018.
15. GUANGYU C., XIN C., YI S. Profile distribution of soil organic carbon under different land use type in Sanjing Plain. Paper presented at the $19^{\text {th }}$ World Congress of Soil Science, 2010.

16. BOUWMAN A., BOUMANS L., BATJES N. Emissions of $\mathrm{N} 2 \mathrm{O}$ and NO from fertilized fields: Summary of available measurement data. Global biogeochemical cycles, 16 (4), 6, 2002.

17. IPCC. The physical science basis. Contribution of Working Group I to the fourth assessment report of the Intergovernmental Panel on Climate Change, 996, 2007.

18. WANG Q., WANG S. Soil organic matter under different forest types in Southern China. Geoderma, 142 (3-4), 349, 2007.

19. DEEKOR T., IWARA A., OGUNDELE F., AMIOLEMEN S., ITA A. Changes in soil properties under different land use covers in parts of Odukpani, Cross River State, Nigeria. Journal of environment and ecology, 3 (1), 86, 2012.

20. RAUT N., SITAULA B.K. Assessment of fertilizer policy, farmers' perceptions and implications for future agricultural development in Nepal. Sustainable Agriculture Research, 1, 37838, 2012.

21. ALI S., HAYAT R., BEGUM F., BOHANNAN B. J. M., INEBERT L., MEYER K. Variation in soil physical, chemical and microbial parameters under different land uses in Bagrot valley, Gilgit, Pakistan. Journal of the Chemical Society of Pakistan, 39 (1) 2017.

22. SULTAN I., FARIDA B., KARAMAT A., SHER A., SHAUKAT A., REHMAT K., ALI H., DURRANI S. Assessment of soil quality under different land use practices in Altit Valley, Hunza Nagar, Gilgit-Baltistan. Paper presented at the Proceedings of the International Conference on Forests, Soil and Rural Livelihoods in a Changing Climate, Kathmandu, Nepal, 27-30 September 2014.

23. BEGUM F., ALI K., KHAN M. Z., ISHAQ S., ALI H., AHMED S., MUMTAZ S. Effect of landslideinduced flood on soil physico-chemical properties in the mountainous landscape, Northern Pakistan. FEBFresenius Environmental Bulletin, 27 (12), 8128, 2018.

24. HUSSAIN A., ALI S., BEGUM S., HUSSAIN I., ALI H. Climate Change Perspective in Mountain Area: Impacts and Adaptations in Naltar Valley, Western Himalaya, Pakistan. FEB-Fresenius Environmental Bulletin, 28 (9), 6683, 2019.

25. BEGUM F., ALAM M., MUMTAZ S., ALI M., WAFEE S., KHAN M. Z., ALI K., HUSSAIN I., KHAN A. Soil Quality Variation under Different Land Use Types in Haramosh Valley, Gilgit, Pakistan. International Journal of Economic and Environmental Geology, 10 (2), 32, 2019.

26. MCLEAN E. Soil pH and lime requirement. Methods of soil analysis: Part 2 Chemical and microbiological properties, 9, 199, 1983.

27. RAYMENT G., HIGGINSON F.R. Australian laboratory handbook of soil and water chemical methods: Inkata Press Pty Ltd, 1992.

28. NELSON D.W., SOMMERS L.E. Total carbon, organic carbon, and organic matter. Methods of soil analysis: Part 3 Chemical methods, 5, 961, 1996.

29. SCHUMACHER B. AMethods for the determination of total organic carbon (TOC) in soils and sediments, 2002.

30. MALIK D., KHAN M., CHOUDHRY T. Analysis manual for soil, water and plants. Directorate of Soil Fertility and Soil Testing, Lahore, Pakistan, 1984. 
31. JONES JR J.B. Laboratory guide for conducting soil tests and plant analysis: CRC press, 2001.

32. AMACHER M.C., O'NEIL K.P., PERRY C.H. Soil vital signs: a new soil quality index (SQI) for assessing forest soil health. Res. Pap. RMRS-RP-65. Fort Collins, CO: US Department of Agriculture, Forest Service, Rocky Mountain Research Station, 12, 65, 2007.

33. REZAPOUR S. Response of some soil attributes to different land use types in calcareous soils with Mediterranean type climate in north-west of Iran. Environmental earth sciences, 71 (5), 2199, 2014.

34. MOGES A., DAGNACHEW M., YIMER F. Land use effects on soil quality indicators: a case study of AboWonsho Southern Ethiopia. Applied and Environmental Soil Science, 2013.

35. BABAR K., KHATTAK R., HAKEEM A. Physicochemical characteristics and fertility status of Gilgit soils. Journal of Agricultural Research, 42 (3-4), 305, 2004.

36. BEGUM F., BAJRACHARYA R.M., SHARMA S., SITAULA B. K. Influence of slope aspect on soil physicochemical and biological properties in the mid hills of central Nepal. International Journal of Sustainable Development \& World Ecology, 17 (5), 438, 2010.

37. PATEL A.H. Soil Study through Correlation Analysis of Chemical Parameters of Agricultural Land from Kheda District in Gujarat. The International Journal of Science and Technoledge, 3 (7), 179, 2015.

38. WANI F.S., AKHTER F., MIR S., BABA Z.A., MAQBOOL S., ZARGAR M.Y., NABI S.U. Assessment of Soil Microbial Status under Different Land Use Systems in North Western Zone of Kashmir. Int. J. Curr. Microbiol. App. Sci, 7 (8), 266, 2018.

39. YIGINI Y., PANAGOS P. Assessment of soil organic carbon stocks under future climate and land cover changes in Europe. Science of the Total Environment, 557, 838, 2016.

40. ALBALADEJO J., ORTIZ R., GARCIA-FRANCO N., NAVARRO A.R., ALMAGRO M., PINTADO J.G.,
MARTÍNEZ-MENA M. Land use and climate change impacts on soil organic carbon stocks in semi-arid Spain. Journal of Soils and Sediments, 13 (2), 265, 2013.

41. KUMAR P., PANDEY P.C., SINGH B., KATIYAR S., MANDAL V., RANI M., VANDANA T., PATAIRIYA S. Estimation of accumulated soil organic carbon stock in tropical forest using geospatial strategy. The Egyptian Journal of Remote Sensing and Space Science, 19 (1), 109, 2016.

42. MUSINGUZI P., TENYWA J.S., EBANYAT P., TENYWA M.M., MUBIRU D.N., BASAMBA T.A., LEIP A. Soil organic carbon thresholds and nitrogen management in tropical agroecosystems: concepts and prospects, 6 (12), 2013.

43. WANG J., WANG X., XU M., FENG G., ZHANG W., YANG X., HUANG S. Contributions of wheat and maize residues to soil organic carbon under long-term rotation in north China. Scientific reports, 5, 11409, 2015.

44. WANG M., SU Y., YANG X. Spatial distribution of soil organic carbon and its influencing factors in desert grasslands of the Hexi Corridor, Northwest China. PloS one, 9 (4), 2014.

45. GE S., XU H., JI M., JIANG Y. Characteristics of soil organic carbon, total nitrogen, and $\mathrm{C} / \mathrm{N}$ ratio in Chinese apple orchards, 3, 213, 2013.

46. AWOTOYE O.O., OGUNKUNLE C.O., ADENIYI S.A. Assessment of soil quality under various land use practices in a humid agro-ecological zone of Nigeria. African Journal of Plant Science, 5 (10), 565, 2011.

47. DENEF K., DEL GALDO I., VENTURI A., COTRUFO M. F. Assessment of soil $\mathrm{C}$ and $\mathrm{N}$ stocks and fractions across 11 European soils under varying land uses. Open Journal of Soil Science, 3 (7), 297, 2013.

48. RAKKAR M.K. Evaluation of soil potassium test to improve fertilizer recommendations for corn. North Dakota State University, 2015. 
